\title{
Professionalising the British film industry: the UK Film Council and public support for film production
}

\author{
Lisa W. Kelly
}

To cite this article: Lisa W. Kelly (2016) Professionalising the British film industry: the UK Film Council and public support for film production, International Journal of Cultural Policy, 22:4, 648-663, DOI: 10.1080/10286632.2015.1015532

To link to this article: http://dx.doi.org/10.1080/10286632.2015.1015532

$$
\begin{aligned}
& \text { (c) } 2015 \text { The Author(s). Published by Taylor \& } \\
& \text { Francis. }
\end{aligned}
$$

\section{曲 Published online: 27 Feb 2015.}

Submit your article to this journal

\section{Article views: 961}

Q View related articles $\sqsubset$

View Crossmark data ð 


\title{
Professionalising the British film industry: the UK Film Council and public support for film production
}

\author{
Lisa W. Kelly* \\ Centre for Cultural Policy Research, University of Glasgow, 13 Professor Square, \\ Glasgow G12 8QQ, UK
}

(Received 11 August 2014; accepted 2 February 2015)

\begin{abstract}
This article examines the UK Film Council's objective to reorganise and reallocate public funding for film from 2000 onwards. I argue that the model adopted by the UKFC was innovative on two levels. First, it separated public funds available for film production into three separate streams and then hired industry professionals to head each individual fund. I also examine how the funds developed over the lifetime of the organisation, with each appointed head shaping the principles of their respective funds in accordance with the wider objectives of the UKFC. Drawing on strategy documents, internal papers and interviews with key personnel, I argue that the UKFC worked to position itself as a 'vanguard organisation' seeking to shake up an independent sector seemingly reliant on state handouts and introduce a commercial perspective to the industry. This mission met an abrupt end, however, when the incoming Coalition government closed down the organisation in 2010.
\end{abstract}

Keywords: UK Film Council; film policy; public bodies; film production; creative industries

\section{Introduction}

This article takes as its focus the UK Film Council's organisation and allocation of public funding for film. Established in 2000 by a New Labour government, the UKFC was the lead body for film until its closure by a Conservative-led Coalition in 2011. In this period it acted as both an advocate for the film industry and a distributor of public funding for film production after taking over the administration of Lottery funding from the Arts Council of England (ACE) and incorporating existing film investment bodies, British Screen Finance and the BFI's Production Department. Drawing on published strategy documents, internal reports and unprecedented access to key UKFC personnel and film industry stakeholders, I begin by contextualising the creation of the UK Film Council and examining the expertise and individuals chosen to lead the organisation. I argue that the original model adopted by the UKFC in terms of organising and allocating public support for film was innovative on two levels. First, it separated public funds available for film production into three separate streams and second, hired industry professionals to head each individual fund. In doing so, the UKFC worked to position itself as a

\footnotetext{
*Email: lisa.kelly@glasgow.ac.uk
} 
'vanguard organisation' seeking to professionalise an independent sector that had seemingly become reliant on state handouts.

On outlining the often contrasting perspectives of the UK independent sector, however, I go on to analyse how the funds developed over the lifetime of the organisation with phase two offering an opportunity to re-evaluate the rationale behind each one and pursue new strategies. As such, each appointed head shaped the principles of their respective funds according to both the wider objectives of the UKFC, but also their own individual background and skill set. This culminated in 2010, first with the internal decision to merge the three streams in an attempt to deal with a decrease in government funding; and second, the incoming Coalition government's decision to abolish the UKFC, with responsibility for public funding for film eventually transferring to the British Film Institute in 2011.

\section{A shifting model: contextualising the UK Film Council}

The UK Film Council was created following the report of the Film Policy Review Group (FPRG) set-up by New Labour's Culture Secretary, Chris Smith, shortly after coming to power in 1997. While there is a paragraph near the end of A Bigger Picture (1998, p. 50) calling for the 'rationalisation of Government machinery in the longer term', there is dispute over how this came to be included. The accepted narrative is that the creation of one 'superbody' responsible for all aspects of film in the UK was a key recommendation of the report (Dickinson and Harvey 2005, Hill 2012). However, as outlined by both Doyle (2014) and Schlesinger (2015), there was little or no discussion of this during the deliberations of the various subgroups set-up to discuss film policy more generally. Instead, the conversation about rationalisation had begun much earlier within the Labour party itself and between Smith and a number of advisors.

The idea of a single body responsible for film can be traced to the mid-1970s, when Labour leader Harold Wilson set-up a working party to 'report back on the future needs of the industry and its relationship with government' (Barber 2013, p. 31). A key recommendation of the subsequent Terry Report (1976) was the creation of a British Film Authority, but Wilson resigned before this could be put in place. While his successor, James Callaghan, sought to follow-up the proposals through the Interim Action Committee (IAC), the plans remained unrealised when Labour lost the 1979 general election (Barber 2013, p. 34). Instead, the IAC was succeeded by the British Screen Advisory Council (BSAC), which was initially administered by the Department of Trade and Industry before transmuting in 1985 into its current form as 'an industrial advisory body funded by the audio-visual industry' (Dry 1995, p. 125). Fiona Clarke-Hackston (interview, 19 March 2013), Chief Executive of BSAC, suggests that for certain stakeholders within the film industry, 'it was thought more likely that Labour [on coming to power again] would create some sort of overarching body' and the continuation of BSAC meant there 'would be something there to build on'. However, by the time consultations began in the late 1990s regarding the creation of a single organisation, BSAC's remit had expanded to include television, video and cable (with games and new media latterly introduced) and was thus no longer best placed to focus solely on film.

Alternative plans for a new film body were also proposed in 1996 by Wilf Stevenson (Nowell-Smith 2012, p. 294), who was then Director of the BFI and is 
now a Labour peer. His proposal was for a British Film Agency, however, with the Centre nationale de la cinematographie (CNC) in France as a model. As explained by Stevenson (interview, 12 Feb 2013), this approach was made up of various 'strands of thinking'. First 'the government of the day was trying to make too many decisions which could be devolved if there was an agency around to do that'. Second, 'since the development of [Margaret Thatcher's] Downing Street seminar [for film in 1990], we had a number of additional film bodies'; this included the British Film Commission, which was responsible for inward investment and British Screen Finance, a public/private partnership set-up to replace the National Film Finance Corporation. Third, following the recent introduction of National Lottery funds for film production by John Major, Stevenson was developing the 'BFI 2000 project which was to try and anticipate the development of the Lottery and use that to invest heavily in film culture'. Feeling there was an 'unhealthy split between the commercial sector [ ] and the BFI which was seen as very much an educational charity', Stevenson believed the creation of a single institution would be of benefit to film in the UK as a whole.

Around the same time, developments north of the border led to the creation of Scottish Screen, which was established in 1997 'as the national body for the promotion of the screen industries in Scotland' (Hibberd 2008, p. 80) and brought together the functions of the Scottish Film Council, the Scottish Film Production Fund, Scottish Screen Locations and Scottish Broadcast and Film Training. Hibberd (2008, p. 80) notes how 'the absence of "film" from Scottish Screen's title acknowledged the increased convergence of media', yet it is debatable whether this was ever put into practice, as throughout its duration film tended to be the agency's primary focus. Nevertheless, its title did allow for the possibility of following BSAC's wider screen industries remit at some stage before it was subsumed within Creative Scotland in 2010. The creation of one unified body had been recommended by the Hydra Associates (1996) report, Scotland on Screen, and thus set a precedent for rationalisation. It was during this period that conversations between Chris Smith and John Woodward (interview, 13 Feb 2013), then CEO of the Producers Alliance for Cinema and Television (PACT), led to Woodward commissioning the same team to review the potential structures of government support for the UK film industry. The subsequent report (Hydra Associates 1997) put forward a number of options, one of which was the creation of a unified agency.

As I have demonstrated, this proposed unified approach to film support in the UK could have taken a variety of forms. Yet, with the creation of the UKFC, Smith eschewed both Stevenson's plans for a reimagined BFI utilising Lottery money to invest in film culture and indeed BSAC's and Scottish Screen's incorporation of a converged media landscape. Instead, the UKFC took the form of a dedicated body, which sought to highlight the perceived special status of film and which was more concerned with its commercial, rather than cultural significance. Of course, this focus was already evident in Smith's formation of the FPRG, which was specifically set-up to provide an action plan for the film industry and the various discussions he had been engaged in with industry stakeholders. As such, Schlesinger (2015) argues that the FPRG worked to provide 'a framework for endorsing a key policy already decided on, as opposed to actually discovering the need for a new agency through a deliberative process'. Moreover, Dickinson and Harvey (2005, p. 425) highlight how the UK Film Council was not subjected to "parliamentary and Civil Service scrutiny' as New Labour did not present a bill on the creation of 
a new film body. This meant that the organisation was 'negotiated with quite a narrow range of trade interests' (Dickinson and Harvey 2005, p. 425).

As I will go on to argue, the creation of the UKFC and appointment of its first board and senior executive emerged from what Schlesinger (2015) describes as a 'network of connections, based on a shared diagnosis of the ills of the UK film industry and what was needed to cure them'. This resulted in a somewhat implicit mission to 'professionalise' the UK independent sector by drawing on industry expertise and creating three separate funding streams to invest in development, support new talent and encourage more commercial modes of film-making.

\section{Rationalisation, expertise and 'aspiration'}

The Film Council (renamed the UK Film Council in 2003) opened its doors in April 2000 as a non-departmental public body working at arm's length from the government. In doing so, it incorporated the British Film Commission, which was established in 1991 to promote inward investment and three existing bodies investing in film production. The longest running of these was the BFI's Production Department (previously Production Board), which had become a stand-alone department in the 1970s specialising in 'experimental and low budget material' (Wickham 2003, p. 9). This is despite the fact that the BFI had been involved in film funding and production as a 'minor and rather unofficial activity' since the 1950s (Dupin 2012, p. 197). British Screen Finance, on the other hand, was set-up by the Thatcher government in 1985 to replace the National Film Finance Corporation. The result became what Simon Perry (Macnab 2013), CEO of the organisation between 1991 and 2000, describes as 'an accidentally interesting model of private/public partnership' with Rank, EMI, Channel 4 and Granada becoming investors, while the company received a direct government grant of $£ 2$ million per year over its lifetime. Finally, the Arts Council of England's Lottery Film Department had only been in operation since 1995 when John Major introduced Lottery funding for film and charged the Arts Council's of England, Wales, Scotland and Northern Ireland with distributing funds. In addition to investing in individual film projects, the Arts Council of England (ACE) set-up the film production franchises scheme in 1997 which allocated $£ 92$ million of funding to three franchises over six years (Caterer 2011).

The UKFC also assumed overall responsibility for the BFI with the latter now receiving its funding through the newly established Film Council, which also appointed the chair of its board. This rather awkward set-up was problematic in terms of the creation of a unified agency as, unlike the other bodies wholly subsumed within the UKFC, the BFI still retained its formal autonomy as an independent charity promoting film culture and heritage and governed by Royal Charter. However, this structure allowed the $\operatorname{UKFC}(2000$, p. 1) to delegate its cultural and educational remit to the BFI, while it focused primarily on the commercial film industry through a 'two-stage plan of action'. Before examining the UKFC's initial plan in more detail, I want to first consider how the underlying principles behind the formation of the UKFC impacted on its overall approach to film support in the UK.

Schlesinger (2015) argues that 'two logics legitimised the creation of the UKFC: rationalisation and expertise'. The first of these, the logic of rationalisation, is 'based on the belief that one agency is better than many because it may concentrate resources and pursue more effective strategic action. This logic also involves a process of disavowal and taking distance from superseded bodies judged to be 
ineffective'. To illustrate this logic, Chris Smith (Macnab 2010, p. 3) explains how he believed there was a need for two things:

One was much greater coherence - hence the idea of bringing everything together under one roof. Second, I wanted to make sure that we brought what one might call the artistic side of British film-making together with the more commercial side so that each could usefully feed off the other.

The latter is perhaps a comment about the performance of larger established cultural organisations, such as the BFI and ACE, when dealing with the commercial aspect of the film industry. For example, Caterer (2011, p. 9) usefully outlines the dominant assumption around lottery funding from the mid-1990s onwards, which Caterer himself finds unfair, namely, 'that it was a terrible misjudgement to allow antiquated cultural institutions like the Arts Councils to have any responsibility over a large-scale economic activity, such as filmmaking'. In contrast, I will demonstrate how the UKFC sought to position itself as a relatively small and dynamic organisation that could respond quickly to issues and was unafraid to challenge existing Lottery guidelines or at least interpret them differently from ACE.

This leads to the UKFC's second logic which was that of 'expertise'. Again, Schlesinger (2015) explains what applying this logic entailed:

First, finding fault with (and disavowing) the know-how and practice of existing agencies. Second, it set a value on specific kinds of expertise as especially credible and effective, thus legitimising them. The next task was to find the right exemplars of embodied knowledge by choosing particular individuals to undertake the necessary task of transformation.

One of the key priorities of the newly formed UKFC was to introduce a professionalism that was seen to be lacking in both the UK film industry and the way in which the Arts Council distributed lottery funding. With regards to the latter, Petley (2002) highlights the sustained media campaign in some quarters that criticised not only the content of British films, but also the fact that many were in receipt of public funding. By the time of the UKFC's launch in 2000, Petley (2002, p. 42) explains that the sums of money allegedly 'wasted' on British films 'had become firmly established on the news agenda' and changing this perception became one of the most pressing issues for the new body given the high-profile nature of its role as a Lottery distributor.

Following on from the FPRG, however, there was also a sense that the UK film industry required structural change if a 'truly durable business sector' was to be achieved (UKFC 2000, p. 1). While this was undoubtedly a longer term undertaking, the initial strategic mission handed down to the agency by the Department of Culture, Media and Sport (DCMS) was 'to develop a sustainable UK film industry' (UKFC 2000, p. 5), which caused some confusion within the wider sector. The term 'sustainable' was unhelpful because, as explained by CEO John Woodward (interview, 13 Feb 2013), it 'lacks any kind of clarity'. Without a satisfactory definition provided by the government, the notion of sustainability was difficult to achieve as it could be interpreted in various ways. For example, Barratt (2010) helpfully distinguishes between 'hard' and 'soft' conceptions of sustainability, with the former implying 'an enterprise capable of perpetuating itself (and, ideally, growing) without outside support or influence' and the latter suggesting 'a given state 
can be maintained at a desired level without exhausting available resources'. For the UK film industry, Woodward (interview, 13 Feb 2013) notes how a pathway to the former appeared unrealistic as 'there is no historical precedent for film industries that are self sustaining without public subsidy and support'. However, Stewart Till (interview, 27 March 2013), Deputy Chair and then Chair of the organisation from its inception until 2009, believes that the overall goal was not to 'wean UK independent producers entirely off the need for public subsidy', but was instead about 'establishing the right sort of aspiration'.

This 'aspiration' was undoubtedly skewed towards commercial film-making, as evident in the expertise sought to lead the organisation. In the first instance, Smith installed Hollywood director Alan Parker as Chair and Stewart Till of PolyGram Filmed Entertainment as his deputy along with John Woodward, formerly of PACT, as CEO. While Till had overseen the FPRG along with the Films Minister Tom Clarke, both Parker and Woodward had recently assumed the same roles at the BFI which Parker (interview, 11 March 2013) describes as an 'old moribund ineffectual organisation ... [where] you couldn't change anything'. With that in mind, Parker (interview, 11 March 2013) expressed a preference for leading the new organisation and set about securing a board 'made up of cutting edge professional film-makers, producers, directors, distributors, it really was the best people'. Jenny Borgars (interview, 3 Dec 2013), who was Head of the UKFC's Development Fund (2000-2007), expands on this:

When [the DCMS] put the Film Council board together it made a very bold statement because they brought very, very successful industry practitioners into it. So if you think about that first Board, it was Tim Bevan [of Universal subsidiary Working Title], Paul Webster who was running Film4, there was Chris Auty who was running one of the franchises [The Film Consortium]. There was Duncan Kenworthy, one of the most successful [UK] producers [and co-founder of film franchise DNA Films], I mean there was Sarah Radclyffe [co-founder of Working Title and aligned with the third film franchise Pathe Pictures] ... basically, it was your wish list of the high hitters in the industry.

Before going on to consider how the presence of such 'high hitters' impacted on the rhetoric espoused by the UKFC and indeed the often contrasting perspectives this prompted both inside and outside of the organisation, I first want to examine the initial strategy relating to the reorganisation and reallocation of public support for film and how this was implemented throughout the tenure period of the original appointed heads.

\section{UKFC funding streams: phase 1}

In terms of the reorganisation and reallocation of Lottery funds, the model adopted by the UKFC was innovative on two levels. First, it separated lottery funds into three different streams in the form of the Development, New Cinema and Premiere Funds and then hired industry professionals to head each one. In the first instance, the decision to create a fund purely for development was particularly welcomed by industry stakeholders as a lack of support in this area had been identified by the FPRG (1998) as a major weakness within the UK film industry. The New Cinema Fund, on the other hand, was more of a continuation of the work carried out by British Screen, the BFI and ACE, with its focus on low-budget features within the 
tradition of cultural film-making and a commitment to working with talent outside the mainstream. In what was perceived as a relatively new approach, the Premiere Fund pursued a more commercial strategy, as it sought to facilitate the production of popular mainstream British films and 'attract significant audiences at home and abroad' (UKFC 2000, p. 14).

By delegating decision-making for investment to qualified professionals (UKFC 2000 , p. 14), the organisation also distanced itself from its predecessors in a number of ways. For example, ACE had lacked expertise in film-making and thus outsourced decision-making to a committee. As explained by one such member, BSAC's Clarke-Hackston (interview, 19 March 2013), the committee met once a month having spent all weekend reading paperwork for no remuneration, but felt bound by lottery constraints as to the types of projects they could approve. This led to some questionable decisions that, as outlined by Petley (2002), were seized on by the media.

British Screen Finance, on the other hand, was a much smaller outfit of around 14 staff with less money at its disposal, but was nevertheless relatively successful in its investments (Minns 2000). However, it was synonymous with one person, its CEO Simon Perry, a situation which, according to Borgars (interview, 3 Dec 2013), was 'both the joy but also the problem with [the organisation]' because decisionmaking appeared to lie in the hands of just one individual. The BFI's Film Production Department had, of course, a long history of supporting cultural films and had gained particular success at certain points over the years (Dupin 2012). However, it lacked experience of investing in commercial film-making and - as indicated by Parker (interview, 11 March 2013) - there was a feeling that as a large organisation, it was too big to affect change quickly. For example, for the year 2000, the BFI had 403 members of staff funded by DCMS grant and operating income working across film exhibition, collections, education, production and associated administration and services (BFI 2000). By contrast, the UKFC had 54 management and administration staff in its first year of operation (UKFC 2001). Thus, as a new and smaller organisation bringing in industry expertise and with a decidedly commercial outlook, the UKFC sought to usher in a new era of public support for film.

\section{Development fund}

With an allocation of $£ 5$ million per year, the Development Fund became one of the largest of its type in Europe and was headed by Jenny Borgars, previously a development executive for British Screen. While this suggests a degree of continuity with what had gone before, British Screen had a much smaller budget and only developed material with a view to investing in the production (Finney 1996, p. 23). In contrast, the UKFC aimed to develop independent projects, which could go on to seek production investment from a wide range of sources including, but not limited to, its own production funds.

The development fund not only invested in individual projects, but also a range of production companies through its slate funding initiative. This was an attempt to create more 'sustainable' production companies, and thus satisfy the UKFC's wider objective. As producers within the UK independent sector tended to work on a project-by-project basis, slate funding offered production companies a larger sum of investment (from between $£ 50,000$ and $£ 500,000$ over the years in which it operated), which could be used to hire staff, create a culture of development and 
essentially build a slate of projects to work across at any given time. For Borgars (interview, 3 Dec 2013), the slate funding initiative occurred in two distinct cycles. The initial approach was simply to back a range of producers and leave it 'entirely in the producers' hands' as to how to best utilise the money available to them, while the second cycle became, what she describes as,

a more market driven form of slate funding, wherein we were encouraging producers to get distribution financing feedback at an early stage, we were encouraging them to do partnership financing [or] if they were of a certain size to see if they could [act as an] umbrella for some of the younger producers.

The difficulty with the Development Fund, however, both in terms of slate funding and individual projects, is that the development process occurs too early in the life cycle of film to judge effectively whether the investment has been a success. As Borgars (interview, 3 Dec 2013) notes in relation to slate funding in particular, 'if you really want to build a company that can work, you give them funding over ten years, you let them fail miserably for a while and then they will start to get it'. However, even the Lottery film franchises that occurred during ACE's tenure were only funded over six years, with success usually coming during the latter stages of the agreement or indeed once the funding had been concluded (Caterer 2011).

Examples of films that the Development Fund invested in during Borgars's tenure and which went on to be successful include the critically acclaimed The Magdalene Sisters (2002), winner of the Golden Lion at the Venice International Film Festival and KiDULTHOOD (2006), which performed particularly well at the box office with young adult audiences, a traditionally weak demographic when it comes to UK film. While The Magdalene Sisters went on to secure production funding from the New Cinema Fund, KiDULTHOOD attracted investment from elsewhere. Notably, Jonathan Glazer's critically acclaimed 2014 film Under the Skin, featuring Scarlett Johansson, was in development for such a lengthy period that it first received UKFC funding from Borgars in 2005. Again, this demonstrates the time it can take before being able to judge whether an investment is successful.

\section{New cinema fund}

The New Cinema Fund was allocated $£ 5$ million a year to support new talent and encourage innovative film-making through the use of digital technology for lowbudget features and short films (UKFC 2000). It also had a 'strong commitment to supporting work from the regions and from black, Asian and other ethnic minorities' (UKFC board paper April 2005). Producer Paul Trijbits (interview, 17 Dec 2013) was selected to head the fund having built a reputation for producing films of this kind, in the form of Richard Stanley's Hardware (1990) and Danny Cannon's The Young Americans (1993) which he describes as 'quite commercially minded [and] aiming at a wider, younger audience', thus differentiating them from 'the movies people were generally making in Britain [at the time]'.

Although the outlines for the three funds were put in place by the original UKFC board, they lacked a detailed brief, therefore, each fund head was able to determine how best to utilise the money available to them in accordance with the wider aims of the organisation. The approach adopted by Trijbits (interview, 17 Dec 2013) was that that New Cinema Fund should create 'multiple points of entry for talent; new talent, existing talent ... talent we know, talent we didn't know', 
and while producing single features was always a key aim, he also set out to create a broader talent base through a number of short film schemes. This included a nationwide Digital Shorts programme that was run by the nine newly established Regional Screen Agencies and the more bespoke Cinema Extreme scheme for advanced film-makers. In seeking to react to ongoing developments within the industry, the New Cinema Fund also made funds available for shorts costing just $£ 1000$ each, as digital technology made it increasingly possible to produce microbudget projects. This was in addition to micro-budget features, such as Bille Eltringham's experimental This is Not a Love Song (2002), which was majority funded by the UKFC and became the first UK film to be simultaneously distributed in cinemas and online.

In terms of developing feature film talent, the New Cinema Fund also had a number of successes during Trijbits's tenure. For example, he invested in Bloody Sunday (2002) by Paul Greengrass, who went on to direct two films in the Bourne film franchise and Red Road (2006) by Andrea Arnold, who was awarded the Jury Prize at Cannes for both this, her first feature, and her follow-up film Fish Tank (2009). The groundbreaking documentary Touching the Void (2003) by Kevin MacDonald was an example of the type of experimental film-making encouraged by the fund, while the award winning A Way of Life (2004), by Ghanaian-British director Amma Asante, demonstrated its commitment to diversity, with Asante going on to direct the acclaimed period drama Belle (2014) dealing with race and class in eighteenth century Britain.

\section{Premiere fund}

The Premiere Fund had a larger allocation of $£ 10$ million to encourage the production of profitable films, a difficult thing to achieve even for Hollywood studios, which are able to spread risk and generate revenue through various streams. It was particularly tricky in the UK context, however, given the strict guidelines around Lottery funding. For example, as outlined by Caterer (2011, p. 22), ACE and British Screen had attempted something similar in the mid-1990s through the experimental scheme The Greenlight Fund:

The idea behind this fund was to attract directors of 'international repute' into the industry through larger awards made to films between $£ 3$ million and $£ 10$ million ... However, the Greenlight Fund was difficult to reconcile with British Screen's policy of 'additionality': the idea that 'Money could only be granted if the film would otherwise not be made.'

If a film was supposedly commercial with a relatively high budget and key talent attached, then the market was expected to oblige with regards to funding. Yet, as Caterer (2011, p. 113) goes on to suggest, the UKFC was able to adopt such an approach just five years later as the concept of additionality had become 'less politically charged', while the solicitation of projects, 'once considered a dangerous step towards "croney-ism", was now regarded as strategically vital to the success of Lottery funding for film. Nevertheless, in contrast to the Development and New Cinema Funds, the rationale behind the Premiere Fund was trickier to defend with regards to the distribution of public money, therefore the focus was as much on 'attracting audiences' as it was on generating profits (UKFC 2000, p. 14). 
Against this backdrop, the Premiere Fund was headed by Robert Jones, the executive producer of Sirens (1993), The Usual Suspects (1995) and Hard Eight (1996) who also had experience of film distribution, acquisition and financing. With an original investment ceiling of $£ 1$ million per film, the aim was to invest in eight to ten films per year ranging in budget from $£ 1$ to $£ 8$ million. However, one of the first awards made by Jones was of $£ 2$ million to the costume drama Gosford Park (2001) by Hollywood director Robert Altman, a decision that proved prudent as the film not only went on to win an Oscar, Golden Globe and BAFTA, but also fully recouped its UKFC investment by 2003. This early success was crucial as it gave the nascent organisation the hit film it needed and began to generate more positive media coverage for Lottery funding for film.

This was followed by further awards which broke the original investment ceiling of $£ 1$ million, most notably the animation Valiant ( 2.5 million), family film Five Children and It (£2.1 million), The Constant Gardener ( $£ 1.9$ million) by Fernando Meirelles and Mike Leigh's Vera Drake (£1.2 million). Of these, the latter two performed best, attracting numerous awards and critical acclaim, while also recouping part of their investment. Other films were not as well-received, however, such as the controversial Sex Lives of the Potato Men (2004), which was awarded over $£ 1.5$ million from the Premiere Fund and was dubbed 'one of the worst films ever made' (Humphries 2004). Hill (2012, p. 339) explains that although it was defended by the UKFC 'on the grounds that it would appeal to young workingclass males rather than middle-aged, middle-class critics (and the film did, it seems, eventually turn a profit on the back of video and DVD sales)', it also demonstrates 'how the funding of a film on an apparently "commercial" basis could nonetheless attract considerable hostility from the very same newspapers that had previously lamented the lack of commercial success of Lottery-funded films'.

One issue that arose in relation to the hiring of professionals was that, in the case of the New Cinema and Premiere Funds, both Trijbits and Jones were given executive producer credits for the films they chose to invest in, despite dispensing public money. On speaking to both, there was a feeling that as practitioners, they had been hired for their production expertise and were actively involved in making the films happen by helping raise the necessary finance. Being able to do this, rather than simply 'ticking boxes', as phrased by Jones (interview, 19 Dec 2013), was what made the role attractive. Nevertheless, it attracted controversy within the independent sector as I will now discuss.

\section{The rhetoric of the UKFC: inside and outside perspectives}

Having carried out almost 50 interviews over the course of a wider research project with UKFC board members, senior executives, policy-makers and film industry stakeholders, what emerged was often contrasting perspectives of how those within the organisation viewed the UKFC and the opinions of the wider film community. This is important because as a unified body, the UKFC performed the dual role of providing strategic leadership for the industry, while also acting as a Lottery distributor investing in particular projects, schemes and initiatives. Yet, the organisation often struggled to articulate its position to the various constituencies which make up the wider UK film industry, with its mission to 'professionalise' the industry remaining implicit, rather than explicit. This difficulty was also highlighted by the DCMS in its 2007 Peer Review: 'should [the UKFC] promote film 
production generally or protect British film? It should do both, whilst improving relations with smaller, indie producers' (see Olsberg SPI and Barratt 2010, p. 93). Thus, it was the relationship with the independent sector, which was largely reliant on public funding for production, which proved the most difficult with independent producers being vocal in their criticism of the organisation.

Producer Tanya Seghatchian (interview, 9 Jan 2014), Head of the Development Fund between 2007 and 2010, perhaps best sums up how the UKFC sought to see itself when she describes it as a 'vanguard organisation':

It was the first and only time really that there was a cohesive group of people who were going to act as change agents for the benefit of the industry as a whole, and to take on board all the interested parties and all the vested interests and enable us to create a viable cross-sector industry.

Jenny Borgars (interview, 3 Dec 2013), who preceded Seghatchian in the same role, similarly explains how from its inception, the UKFC

deliberately took a stance to say 'we are a shining new beacon for how public money is going to be invested in film' and a very aggressive stance in effectively saying, 'these are the flaws that we judge in the industry as it stands [and] there are things we are seeking to change and address'.

This is echoed by Robert Jones (interview, 19 Dec 2013), Head of the Premiere Fund from 2000 to 2005, who states 'from an internal point of view I think, at the beginning, there was a real crusading sense amongst many of us because it felt like there was a ship that needed turning round in the way things were approached in the industry'.

This discourse, which highlights the need for 'change' within the industry and particular 'flaws' to be addressed (in addition to Jones's nautical metaphor), is encapsulated in Parker's (UKFC 2000, p. 1) foreword to the agency's first public statement in which he declares, 'sometimes within the UK film industry it's hard to know if we're waving or drowning'. While many saw this rhetoric as 'brave' or 'bold', in that it was explicit about shaking up the industry, others felt it tipped over into 'arrogance' or 'hubris', with these being the most frequent terms to arise in interviews with UK independent producers, many of whom also served on the UKFC board at one time or another. According to one such producer and board member,

there was the feeling that the UKFC arrived and they were the professionals, because they were largely people who had come from the studio system where money is never an issue, everything is well capitalised, decisions can be made quickly. (interviewee 16, 12 March 2013)

For those working in the UK film sector then, an under-capitalised industry relying on public subsidy, what resulted was to a certain extent an 'us and them' situation making it difficult to work collaboratively with producers. As explained by another producer and board member (interviewee 12, 19 Feb 2013), 'there was an extremely arrogant assumption that the [UKFC] executives knew better than the constituents they were serving ... which was ironic because that's where they were all recruited from'. John McVay (interview, 12 March 2013), CEO of the producers association PACT, supports this view explaining how, in his opinion, UKFC 
executives were essentially saying to the indigenous production sector, "we will give you money but you're not making the sort of films we think you should be making. Which, to me, is hubris of the worst sort in any kind of public agency'.

It was important, therefore, to have tenure periods for the funds so that they did not become associated with particular individuals or seen to promote certain types of projects and the introduction of new fund heads between 2005 and 2007 offered an opportunity to re-evaluate the rationale behind each one and deliberately pursue new strategies. In doing so, Phase 2 saw the end of executive producer credits and the recruitment of fund heads with different backgrounds and skill sets to their predecessors. Moreover, since 2004, both the Development and Premiere Funds had experienced a reduction in the money available to them, with the former now having $£ 4$ million to spend and the latter $£ 8$ million, while the New Cinema Fund remained the same (UKFC 2004). As outlined below, these changes resulted in a slight shift from the rhetoric around industry expertise, which had been the defining characteristic of the UKFC's distribution of public funds, to a stronger acknowledgement of the public service element of the role and an attempt to create a more supportive environment for the independent sector by providing smaller investments across a wider range of projects.

\section{UKFC funding streams: phase 2}

The Development Fund saw Borgars succeeded by Tanya Seghatchian, producer of the award winning British film My Summer of Love (2004), who was also instrumental in bringing the Harry Potter franchise to the big screen. As a practitioner with first-hand experience of the development process, her appointment on one level is indicative of the UKFC's tradition of delegating decision-making to qualified professionals. However, on discussing her reasons for joining the agency after being involved in one of the most successful franchises in film history, Seghatchian (interview, 9 Jan 2014) explicitly acknowledges the 'public service' nature of the role, viewing the UKFC as 'absolutely the environment in which I'd be able to give back to my industry'. With this in mind, Seghatchian (interview, 9 Jan 2014) was largely welcomed by the independent sector due to her attempts to provide more autonomy for those film-makers securing investment from the Development Fund:

My primary objective was to create a distinction between the first timers and newcomers who I felt needed more support ... and the more experienced individuals who I felt could probably manage things very effectively on their own ... So I put in a distinction between first time screenwriters and film-makers, and experienced practitioners, which hadn't existed before.

This approach arose from having been involved in the process from the 'other side' during times as a producer when she would have appreciated further intervention from funders or indeed felt more experienced than those providing investment. As such, applications from emerging talent were assessed quarterly, while those from more established practitioners were reviewed on a rolling basis.

During her tenure, Seghatchian also sought to revise the Development Fund's approach to slate funding, replacing it with the Vision Awards scheme. The original slate funding initiative was in some ways reminiscent of ACE's film franchise scheme, albeit on a much smaller scale, and over its two cycles exchanged an 
initial 'hands off' style for a more 'market driven approach' highlighting specific objectives. Seghatchian (interview, 9 Jan 2014) still felt however that while the initiative had been 'useful for the period it had been in place ... [awards] were essentially favouring the bigger companies with relationships with distributors and sales companies built in'. In an attempt, therefore, to use public money to create more diversity in the independent sector, the Vision Awards sought to invest less funds across more production companies if they could 'demonstrate strong talent relationships and a [particular] vision [that filled] strategic gaps in the industry'.

This notion of less investment across a wider range of projects and companies was to characterise Phase 2 of the UKFC's funding streams. For example, at the New Cinema Fund producer Trijbits was replaced in 2006 by Lenny Crooks, who came from a public sector background, having run the Glasgow Film Office and established the Glasgow Film Fund, which successfully leveraged public and private investment for film production. In contrast, perhaps, to his predecessor, Crooks (interview, 27 Jan 2014) not only saw himself as a public servant, but was explicit about the fact that those employed by the UKFC should be aware of their public service role: 'My view, coming in, was that the Funds had begun to overlook the public service element, becoming a little bit studio-like'. In part, he felt this had created less distinction between Premiere and New Cinema Fund films as the latter had begun to move towards the 'centre ground'.

In an attempt then to reconnect with the original objectives laid out for the fund in 2000, namely to discover new talent, utilise digital technology and work outside the mainstream, Crooks (interview, 27 Jan 2014) explains how he sought to invest in a wider range of lower budget films:

Before handover, the average budget for a New Cinema Fund film was $£ 2.7$ million and [the UKFC] put over $£ 550,000$ into each film. After I came in, the average budget was $£ 1.1$ million and we put in $£ 350,000 \ldots$ that gives the numerical sense of us pulling away from the centre ground, and that gave us a greater space in terms of perception between what the New Cinema Fund and the Premiere Fund was.

Applicants were also required to present a clear festival strategy as this was considered the best way for non-mainstream films to gain critical attention and reach an international market. During Crooks's tenure at the New Cinema Fund, this approach gained considerable success, most notably with James Marsh's documentary Man on Wire (2008), which was awarded both the Grand Jury Prize and Audience Award at the Sundance Film Festival before securing US distribution. With successful box office returns, Man on Wire not only went on to fully recoup its UKFC investment, but also won an Oscar and BAFTA. Other examples of the diversity of films the New Cinema Fund invested in include: AdULTHOOD (2008), Noel Clarke's successful follow-up to KiDULTHOOD, political comedy In The Loop (2009), a spin-off from the BBC television series The Thick of It (2005-) and Andrea Arnold's award-winning second feature Fish Tank, with the latter two also receiving development funding from the UKFC.

A similar shift had also occurred at the Premiere Fund where producer Jones was replaced in 2005 by Sally Caplan (interview, 29 Nov 2007), who came from a distribution and acquisitions background and saw her role as investing in films that would 'connect more with audiences'. As such, her primary concern was generating box office figures and international sales for cinema, DVD and television, rather 
than securing critical acclaim, festival selection and awards success. In contrast to the $£ 2$ million given to the award-winning Gosford Park, which now represented a quarter of Caplan's $£ 8$ million budget, her approach echoed that of Seghatchian and Crooks, as she felt it more appropriate to invest less money into a higher number of films. It is important to note that the wider economic landscape had changed during this period, with the second set of fund heads experiencing a more pressured environment as the recession and subsequent global financial crisis made it harder to find financing for films. Thus, although the UKFC's Business Affairs department had always been involved in approving the investments made by each individual fund, it was particularly vital that those films at the commercial, rather than cultural end of the spectrum had a 'plausible financial plan' in place before the UKFC committed money (Caplan interview, 29 Nov 2007).

Examples of the type of commercial films the Premiere Fund invested over $£ 1$ million in during Caplan's tenure include: the 2007 reboot of the St Trinian's franchise, alien invasion movie Attack the Block (2011) and Streetdance 3D (2010), which was not only credited with 'discovering and nurturing new creative talent in the UK', but also enjoyed 'the most successful opening weekend of any film [the UKFC] has supported in its 10-year history' (BBC News 2010). While each of these examples can be interpreted as equating commercial film-making with young adult cinema-going audiences, the UKFC's greatest success on an international scale was the multiple Oscar winning The King's Speech (2010), a period drama that received initial investment from the Development Fund followed by $£ 1$ million from the Premiere Fund in 2009.

Yet, at the same time as the UKFC was receiving plaudits for being the only public funder to recognise the film's potential, both the funding streams and then the UKFC itself came to an abrupt end due to the impact of the financial crisis on funding for public agencies and the arrival of the Conservative-led Coalition government. In relation to the first point, an internal decision was taken in 2010 to merge the three streams into one unified Film Fund headed by Seghatchian with $£ 15 \mathrm{~m}$ a year to invest. Any concerns the industry may have had regarding how the available money would now be targeted across development, low-budget and commercial film-making proved to be short lived as the Coalition announced the closure of the Film Council within a matter of months, as part of a cost-cutting drive designed to improve efficiency and reduce costs (Shoard 2010), with responsibility for Lottery funding and the wider UK film sector eventually transferring to the BFI in 2011 .

\section{Conclusion}

This account of the creation of the UKFC, its original funding strategy and how this developed over its lifetime demonstrates some of the issues surrounding the policy process and the ways in which it is enacted by key individuals. I argue that the underlying principles behind the formation of the UKFC impacted on its overall approach to film support in the UK, focusing on the commercial aspect of the industry and providing an action plan that set out to 'professionalise' the independent sector by incorporating specific expertise and establishing a certain type of aspiration. In practice, this was achieved by separating the funding into three distinct streams to invest in development, support new talent and encourage more commercial modes of film-making, which, through a number of well-chosen 
investments, resulted in several successes that helped turn around media perceptions of Lottery funding for film.

However, the rhetoric and methods employed by the UKFC were not always welcomed by the very constituents it was supposed to be serving, as the organisation struggled to articulate its position and appeared to privilege commercial expertise over the public service aspect of distributing public funding. Recognition of this and a subsequent shift to address such issues in the second phase of the funds was largely acknowledged by the independent sector, with one experienced independent producer explaining how, in the latter years of the UKFC, 'there was an attempt to engage in a more supportive way' (interviewee 30, 12 March 2013). For others, however, this shift was considered 'too late' to affect real change (interviewee 12, 19 Feb 2013), as the UKFC by this time faced reduced funding and eventual closure. Moreover, the relatively small amount of public funding available to the UKFC throughout its tenure was also unlikely to bring around the structural change required within the industry.

The trajectory of this particular element of the UKFC's wide-ranging remit is significant for the way in which it illustrates certain tensions relating to public support for film production. First, is the amount of time and funding public agencies invest in schemes and initiatives before being able to judge whether they have been a success. Second, is the impact tenure periods have on the types of projects funded and relationships cultivated with constituents. With regards to the UKFC, the initial strategy relating to the reorganisation and reallocation of public funds was revised in Phase 2, offering an opportunity to reflect and react to criticisms within the industry; and indeed, both phases can claim success in different ways. However, if the overall objective was to develop a 'sustainable' industry, in either its 'soft' or 'hard' conception (Barratt 2010), then more time and money was required, but this was made impossible due to political decision-making regarding reduced funding followed by the eventual abolition of an organisation that was beginning to find its way.

\section{Acknowledgements}

This work comes out of the AHRC funded project AH/J00457X/1. The project's research team conducted the interviews with the informants cited and my thanks go to both the interviewees for taking part and my colleagues, Professor Gillian Doyle, Professor Philip Schlesinger and Professor Raymond Boyle, for their comments on this article.

\section{Funding}

This work was supported by the Arts and Humanities Research Council [grant number AH/ J000457X/1].

\section{References}

Barber, S., 2013. The British film industry in the 1970s. Basingstoke: Palgrave Macmillan.

Barratt, J., 2010. On sustainability: UK film policy after the UK Film Council [online]. Bigger picture research. Available from: http://www.biggerpictureresearch.net/2010/12/onsustainability-uk-film-policy-after-the-uk-film-council.html [Accessed 21 January 2013].

BBC News, 2010. Streetdance beats Prince of Persia at UK cinemas [online]. Available from: http://www.bbc.co.uk/news/10149644 [Accessed 23 July 2014].

British Film Institute, 2000. Annual Review 1 April 1999 - 31 March 2000. London: BFI. 
Caterer, J., 2011. The people's pictures: national lottery funding and British cinema. Newcastle Upon Tyne: Cambridge Scholars Publishing.

Department for Culture, Media and Sport, 1998. A bigger picture. The report of the film policy review group. London: DCMS.

Dickinson, M. and Harvey, S., 2005. Film policy in the United Kingdom: new labour at the movies. The political quarterly, 76 (3), 420-429.

Doyle, G., 2014. Film support and the challenge of 'Sustainability': on wing design, wax and feathers, and bolts from the blue. Journal of British cinema and television, 11 (2-3), $129-151$.

Dry, C., 1995. Film and television in education: the handbook of the British Universities film \& video council. London: Blueprint.

Dupin, C., 2012. The BFI and film production: half a century of innovative independent filmmaking. In: G. Nowell-Smith and C. Dupin, eds. The British film institute, the government and film culture, 1933-2000. Manchester: Manchester University Press, 197-218.

Finney, A., 1996. Developing feature films in Europe: a practical guide. London: Routledge.

Hibberd, L. 2008. Creative industries policy and practice: a study of BBC Scotland and Scottish screen. Thesis (PhD). University of Glasgow.

Hill, J., 2012. 'This is for the Batmans as well as the Vera Drakes': economics, culture and UK government film production policy in the 2000s. Journal of British cinema and television, 9 (3), 333-356.

Humphries, A., 2004. If it's too smutty, you're too snooty [online]. The Guardian. 27 Feb Available from: http://www.theguardian.com/film/2004/feb/27/2 [Accessed 20 January 2014].

Hydra Asscoiates, 1996. Scotland on screen: the development of the film and television industry in Scotland. Glasgow: Hydra Associates.

Hydra Associates, 1997. A review of potential structures of government support for the film industry in the United Kingdom. London: PACT.

Macnab, G., 2010. The life and death of the UK Film Council [online]. Sight \& sound, October. Available from: http://old.bfi.org.uk/sightandsound/feature/49647 [Accessed 7 Dec 2012].

Macnab, G., 2013. Thatcher's film legacy [online]. Screen international. April. Available from: http://www.screendaily.com/features/in-focus/thatchers-film-legacy/5053937.article [Accessed 4 July 2014].

Minns, A., 20 Jan 2000. British screen to be folded into Film Council [online]. Screen international. Available from http://www.screendaily.com/british-screen-to-be-folded-intofilm-council/401087.article [Accessed 4 July 2014].

Nowell-Smith, G., 2012. Towards the millennium. In: G. Nowell-Smith and C. Dupin, eds. The British film institute, the government and film culture, 1933-2000. Manchester: Manchester University Press, 272-303.

Olsberg, S.P.I. and Barratt, J., 2010. UK Film Council performance: assessment. London: UKFC.

Petley, J., 2002. From brit-flicks to shit-flicks: the cost of public subsidy. Journal of popular British cinema, 5 (1), 37-52.

Schlesinger, P., 2015. The creation and destruction of the UK film council. In: K. Oakley and J. O'Connor, eds. The Routledge companion to the cultural industries. London: Routledge. Forthcoming.

Shoard, C., 2010. Government to axe UK Film Council [online]. The Guardian, 26 July. Available from: http://www.theguardian.com/film/2010/jul/26/uk-film-council [Accessed 20 January 2013].

Terry, J., 1976. The future of the British film industry: report of the Prime Minister's working party. London: HMSO.

UK Film Council, 2000. Towards a sustainable UK film industry. London: UKFC.

UK Film Council, 2001. Report and group accounts for the year ended 31 March 2001. London: UKFC.

UK Film Council, 2004. Our second three year plan. Funding and policy priorities April 2004 to March 2007. London: UKFC.

UK Film Council, 2005. The production funds: Board paper. London: UKFC.

Wickham, P., 2003. Producing the goods? UK film production 1991-2001. London: BFI. 